\title{
Kebijakan Formulasi Sanksi Teguran (Reprimand) Oleh Hakim Terhadap Korporasi
}

\author{
Jhuanda Fratama Kharismunandar \\ Fakultas Hukum, Universitas Diponegoro, Semarang \\ Jhuan.fkm@gmail.com
}

Eko Soponyono

Fakultas Hukum, Universitas Diponegoro, Semarang

DOI: 10.23917/jjr.v10i1.10526

\section{Submission \\ Track:}

Received:

10 Maret 2020

Final Revision:

18 Juni 2020

Available online:

31 Juli 2020

Corresponding

Author:

Jhuanda Fratama

Kharismunandar

Jhuan.fkm@gmai

$\underline{\text { l.com }}$

\section{ABSTRAK}

Tujuan : Tujuan dari penelitian ini adalah menggali sanksi administratif korporasi yang diterapkan saat ini dan merumuskan kebijakan formulasi sanksi teguran (reprimand) oleh hakim terhadap korporasi di masa yang akan datang.

Metodologi : Metode penelitian yang digunakan berupa penelitian doktrinal (yuridis normatif) dengan berbagai pendekatan perundangundangan (statute approach), konsep (conceptual approach), analitis (analytical approach), perbandingan (comparative approach) dalam membantu pemecahan rumusan masalah yang beracuan dari literasi dan peraturan perundang-undangan di dalam negeri dan luar negeri.

Temuan : Hasil dari penelitian ini ditemukan bahwa pengaturan sanksi administratif terhadap korporasi selama ini dinilai masih kurang efektif. Sanksi administratif sebagai bentuk pemaksaan oleh pemerintah kepada korporasi yang melakukan pelanggaran. Penerapan sanksi teguran tertulis terdapat banyak kelemahan dalam pelaksaannya sehingga hakim harus memutus dengan sanksi pidana.

Kegunaan : Selama ini penerapan sanksi administratif belum optimal khususnya sanksi teguran yang hanya berpusat teguran dari pemerintah sehingga diperlukan teguran dari penegak hukum terutama hakim supaya memberikan efek jera terhadap korporasi diantaranya kerugian materil dan non materil seperti penurunan saham, ketidakpercayaan kerjasama antar pihak korporasi serta masyarakat dan turunnya reputasi korporasi. 


\begin{abstract}
Kebaruan/Orisinalitas : Penelitian ini memiliki fokus yang mendalam terhadap pembaharuan formulasi sanksi teguran (reprimand) oleh hakim. Sanksi teguran (reprimand) oleh hakim sangat efektif dalam penerapannya, akan banyak korporasi yang dapat dilaporkan dan dikenakan penerapan formulasi sanksi ini berdasarkan kualitas pelanggaran yang dilakukan oleh korporasi.
\end{abstract}

Keywords: Kebijakan Formulasi, Korporasi, Teguran

\title{
PENDAHULUAN
}

Korporasi merupakan badan hukum yang paling tepat untuk menyalurkan ide dan pengembangan usaha dalam peningkatan mutu kuliatas untuk mencapai suatu tujuan. Namun, dalam perjalanannya korporasi melibatkan hukum sebagai kaidah tertinggi untuk dipatuhi dan ditaati sebagai pedoman untuk menjalankan kegiatan usahanya. Suatu korporasi bisa sewaktuwaktu melakukan penyimpangan dari tujuannya, hal ini tidak lain disebabkan oleh perbuatan manusia yang ingin mencari keuntungan sebanyak-banyaknya dengan menghalalkan segala cara. Oleh sebab itu bagi korporasi yang melakukan pelanggaran harus di adili seadil-adilnya sebagaimana hukum ditegakkan berdasarkan kualitas pelanggaran yang dilakukan.

Suatu pelanggaran yang dilakukan oleh korporasi merupakan perbuatan melawan hukum dari undang-undang yang mengatur sanksi korporasi itu sendiri. Korporasi adalah suatu perusahaan yang memiliki sekumpulan orang atau harta kekayaan yang terorganisir dengan struktur yang baik di dalamnya, sifat korporasi tersebut baik berbadan hukum maupun bukan berbadan hukum yang dapat di jelaskan dalam Pasal 1 ayat (1) Undang-Undang Nomor 31 Tahun 1999 Tentang Pemberantasan Tindak Pidana Korupsi (UU Pemberantasan Tindak Pidana Korupsi), Undang-Undang Nomor 22 tahun 1997 Tentang Narkotika (UU Narkotika), Undang-Undang Nomor 5 tahun 1997 Tentang Psikotropika (UU Psikotropika), UndangUndang Nomor 8 tahun 2010 Tentang Pencucian Uang (UU Pencucian Uang), UndangUndang Nomor 21 Tahun 2007 Tentang Tindak Pidana Perdagangan Orang (UU Perdagangan Orang) dan lain-lainnya.

Kebijakan formulasi sanksi administratif harus menjadi prioritas dalam mencerminkan prinsip keadilan atau lebih dikenal proporsionalitas, jika tidak dilaksanakan maka dapat meruntuhkan suatu kepercayaan masyarakat terhadap proses peradilan hukum yang formal (due process of law) yang dianggap tidak adil (Schneider, 2012). Kebanyakan kasus dalam 
penegakkan keadilan yang tidak terlepas dari pergesaran hukum yang memperbolehkan penerapan sanksi sebagai jalan tengah (Hirsch, 2001).

Pengaturan di dalam Undang-Undang Nomor 13 Tahun 2003 Tentang Ketenagakerjaan (UU Ketenagakerjaan), Undang-Undang Nomor 8 Tahun 1995 Tentang Pasar Modal (UU Pasar Modal), Peraturan Pemerintah Nomor 78 Tahun 2015 Tentang Pengupahan (PP Tentang Pengupahan), Peraturan Pemerintah No. 45 Tahun 1995 Tentang Penyelenggaran Kegiatan di Pasar Modal (PP Tentang Penyelenggaran Kegiatan di Pasar Modal), dan Peraturan Menteri Ketenagakerjaan Nomor 20 Tahun 2016 tentang Tata Cara Pemberian Sanksi Administratif, (Permenaker Tentang Tata Cara Pemberian Sanksi Administratif) mengatur sanksi administratif yang dapat dikenakan pada korporasi berupa “teguran, peringatan tertulis, batasan dalam kegiatan hubungan bisnis, denda yang ditentukan untuk membayar sejumlah uang tertentu, penghentian sementara sebagian operasional korporasi atau semua alat produksi, pembekuan korporasi, pembatalan persetujuan dan pembatalan pendaftaran”.

Dari berbagai jenis sanksi administratif terhadap korporasi khususnya mengenai sanksi teguran belum benar-benar memberikan efek jera pada korporasi, efek jera ini tidak berlaku pada pengurusnya melainkan yang menjadi pembahasan formulasi sanksi berupa teguran oleh hakim dimuka umum (public reprimand) adalah untuk memberikan efek jera bagi badan hukum korporasi itu sendiri (Atmaka dan Roestamy, 2019).

Diadakannya formulasi sanksi teguran (reprimand) oleh hakim atas pelanggaran yang dilakukan korporasi adalah dengan memberikan sanksi tanpa pidana (sanksi administratif) yang diputus oleh hakim di muka umum yang kemudian disebarluaskan oleh media cetak, surat kabar, koran, berita, dan sumber informasi lainnya (Kristian, 2017). Sanksi teguran oleh hakim ini merupakan pengembangan dari sanksi teguran, teguran tertulis atau peringatan tertulis yang tercantum dalam beberapa peraturan perundang-undangan. Sanksi teguran yang sudah ada sebelumnya belum menjelaskan secara tegas bahwa teguran tertulis dibuat oleh pemerintah atau ada pihak lain yang memiliki kewenangan khusus, sehingga maksud dari tujuan memberikan teguran tertulis kepada korporasi tidak benar-benar memberikan efek jera. Jika menerapkan sanksi administratif lain misalnya seperti pencabutan izin atau pembekuan korporasi maka akan berdampak kepada para pekerja dan masyarakat seperti terjadi ketidakstabilan perekonomian, meningkatnya kriminalitas dikarenakan faktor pengangguran akibat pemutusan hubungan kerja dan menurunnya pemasukan pajak dan retribusi daerah 
(Rifki, 2019). Perkembangan sanksi teguran oleh hakim di muka umum dalam kebijakannya bahwa teguran keras atau diumumkannya kepada publik atas cacatnya korporasi yang dilakukan oleh pelanggarannya. Hal ini berbeda dengan pidana tambahan berupa sanksi pengumuman putusan hakim yang diatur di dalam Pasal 10 huruf b Kitab Undang-Undang Hukum Pidana (KUHP) menyebutkan sanksi tersebut merupakan sanksi yang berbentuk pidana dan bukan sanksi administratif, telah diketahui bahwa sanksi pengumuman putusan hakim ini belum pernah diterapkan dalam pengadilan di Indonesia (Russel Butarbutar, 2016).

Pentingnya memiliki nama baik dalam suatu korporasi sangat mempengaruhi dunia pemasaran untuk mengenalkan kualitasnya serta keuntungan yang diterima sangatlah menguntungkan perekonomian korporasi, tetapi jika korporasi tersebut bermasalah dengan hukum maka akan berdampak buruk pula seperti dengan diberikan pencelaan (stigma) buruk maka efek jera yang diterima oleh pihak korporasi adalah mendapatkan kerugian materil seperti penurunan saham, kurangnya kepercayaan hubungan antar korporasi yang menjalin kerjasama serta pandangan buruk masyarakat terhadap korporasi, dan memburuknya reputasi korporasi (Amarini, 2016). Sanksi administratif berupa teguran oleh hakim bukanlah upaya terakhir melainkan sanksi yang diutamakan (primum remedium) terlebih dahulu sebelum sanksi pidana dan seperti kesan memberikan kesempatan untuk menjadi lebih baik lagi akibat dari hukuman yang efek jeranya dapat dirasakan benar-benar menyentuh sampai kepada seluruh pengurus korporasi di dalamnya. Jika dikemudian hari korporasi tersebut melakukan pelanggaran di tingkatan yang lebih berat maka sanksi administratif lainnya dapat dijatuhkan kepada korporasi tersebut seperti pencabutan izin korporasi dan sanksi administratif lainnya (Erdiyanti, 2015).

Makna dan hakikat pembaharuan hukum dalam lingkungannya berkaitan erat dengan latar belakang dan urgensi diadakannya pembaharuan hukum itu sendiri. Suatu pembaharuan hukum dapat ditinjau pula dari aspek sosiopolitik, sosiofilosofis, dan sosiokultural atau dari aspek lainnya seperti kebijakan khususnya dalam kebijakan sosial, kebijakan kriminal dan kebijakan penegakkan hukum (Arief, 2014).

Agar urgensi diatas dapat terwujud penulis bermaksud untuk mengkaji dalam beberapa permasalahan yang akan menjadi fokus pembahasan ini adalah perumusan kebijakan formulasi sanksi teguran oleh hakim terhadap korporasi di masa yang akan datang. Karya ilmiah ini diharapkan dapat bermanfaat bagi penulis, pembaca ilmiah, dan masyarakat sekitar sebagai pembelajaran bersama untuk mengenal dan lebih jauh mengetahui tentang penerapan 
sanksi adminitratif yang seharusnya di jalankan dan ditegakkan seadil-adilnya terutama kepada korporasi yang melakukan pelanggaran.

\section{METODE PENELITIAN}

Metode yang dipilih untuk mendukung penelitian adalah penelitian doktrinal dengan pendekatan perundang-undangan (statute approach), konsep (conceptual approach), analitis (analytical approach), perbandingan (comparative approach) dalam membantu pemecahan rumusan masalah. Spesifikasi penelitian yang akan dikaji berupa kerangka perspektif analitis yang dikutip dari beberapa peneliti sebelumnya. Sumber data penelitian ini terdiri dari bahan hukum primer, bahan hukum sekunder untuk dilanjutkan dengan menganalisis secara keseluruhan terhadap peraturan perundang-undangan, literatur, data, dan beberapa dokumen yang terkait serta bahan hukum tersier untuk menjelaskan dan membantu dalam menganalisis bahan hukum primer maupun sekunder.

\section{HASIL DAN PEMBAHASAN}

\section{Tinjauan Korporasi}

Banyak peraturan perundang-undangan tentang korporasi diberikan dan dijelaskan secara konsisten mengenai lingkup korporasi. Korporasi merupakan kumpulan orang atau harta kekayaan yang terorganisir baik berbadan hukum maupun bukan berbadan hukum. Manusia pada umumnya hanya tunduk pada hukum. Selain individu, ada juga subjek hukum lain yang disebut sebagai badan hukum yang mengikat hak dan kewajiban hukum mereka (Rifai, 2014). Ini karena hubungan yang sangat dekat dengan kata "badan hukum" yang diakui di lingkungan hukum. Menurut Garner dan Bryan A, arti yang berasal dari istilah "Korporasi" dalam bahasa Inggris berarti badan hukum atau sekelompok orang yang secara hukum memberi persetujuan setiap orang sebagai subjek hukum setelah para pemegang sahamsahamnya (Marnelly, 2012).

Pengertian korporasi menurut Solomon dan Palmiter:

"A corporation is a structuring device for conducting modern business. It is a framework - a legal person - through which a business can enter into contracts, own property, sue in court, and be sued. It is taxable entity subject property, sales, income, and other taxes. It can range in size from a oneperson business to a multinational conglomerate. It is a capitalist invention for the pooling of capital (from shareholders and lenders), management (from executives), and other factors of production (from 
suppliers and employees). It is a creature of state law; its formation and existence depend on state enabling statutes. A "corporation is an artifice. Nobody has ever seen one. A business conducted as a corporation looks much the same as one conducted in a non corporate form. In the end, a corporation is a construct of the law - a set of legal relationships. It is what the law defines to be".

Berdasarkan pendapat dari beberapa ahli telah menyepakati penyebutan tentang korporasi atau disebut sebagai perusahaan, korporasi cenderung merupakan hasil dari penciptaan pertumbuhan hukum yang mengharuskan korporasi untuk memiliki status subjek hukum dengan hak dan kewajiban berdasarkan undang-undang, termasuk tanggung jawab korporasi terkait. Sejauh menyangkut konsep korporasi, Prasetyo mengusulkan kata perusahaan sebagai definisi yang biasa digunakan oleh para ahli hukum untuk merujuk pada apa yang biasa dalam bidang legislasi lainnya (Arofa, 2018).

Kenneth S. Ferber menyebutkan: korporasi adalah sebuah perusahaan. Korporasi dapat melakukan apa saja yang dapat dilakukan manusia. Korporasi dapat membeli dan menjual properti, baik secara pribadi maupun atas nama mereka, menyebabkan korporasi menuntut dan dituntut secara resmi atas nama mereka (Wibisana, 2016).

Pernyataan klasik oleh Viscount Haldane LC, yang menyatakan: Korporasi adalah sebuah abstraksi, pada dasarnya menunjukkan sifat korporasi itu sendiri. Korporasi tersebut tidak lagi memiliki pikiran dibandingkan dengan perusahaannya sendiri; tujuan yang dilaksanakan dan dibimbing harus terus-menerus dilihat dalam diri seseorang sebagai agen atau delegasi untuk tujuan tertentu, tetapi yang memandu pikiran dan keinginan korporasi yaitu ego dan internal korporasi (Davadi, 2017).

Menurut Satjipto Rahardjo, bahwa korporasi yang dimaksud merupakan: “suatu badan yang diwujudkan dari corpus. Corpus sendiri merupakan suatu wadah atau struktur dari pembadanan yang dimasukkan unsur animus kedalamnya yang membuat badan tersebut memiliki kepribadian. Secara administrasi korporasi merupakan badan hukum yang diciptakan oleh hukum itu sendiri sampai melekat pada masa berakhirnya korporasi, kecuali berakhirnya korporasi ditentukan lain oleh peraturan perundang-undangan (Puspitasari dan Devintawati, 2018).

\section{Pengaturan Sanksi Korporasi dalam Peraturan Perundangan-Undangan di Indonesia}

Menurut Sudarto, bahwa korporasi disebut sebagai subyek daripada hukum, maka sewaktu-waktu hukum yang diberlakukan kepadanya tidak lepas dan mengingat sifat 
keasliannya daripada korporasi itu sendiri (Setiyono, 2005). Penulis akan membatasi kajian sanksi administratif terhadap korporasi dalam beberapa peraturan perundang-undangan seperti UU Ketenagakerjaan, UU Pasar Modal, PP Tentang Pengupahan, PP Tentang Penyelenggaran Kegiatan di Pasar Modal dan Permenaker Tentang Tata Cara Pemberian Sanksi Administratif.

Adapun bentuk sanksi yang digunakan dalam penjatuhan hukuman pada korporasi terdiri dari sanksi administratif dan sanksi pidana. Sanksi administratif terhadap korporasi berupa teguran, peringatan tertulis, batasan dalam kegiatan hubungan bisnis, denda yang ditentukan untuk membayar sejumlah uang tertentu, penghentian sementara sebagian operasional korporasi atau semua alat produksi, pembekuan korporasi, pembatalan persetujuan dan pembatalan pendaftaran, sedangkan sanksi pidana terhadap korporasi berupa sanksi pidana tambahan. Penulis hanya akan membahasa rincian sanksi administratif dan sanksi pidana tambahan dalam bentuk penjelasan sebagai berikut: (Santo, 2016)

\section{a. Sanksi Administratif}

Selain KUHP yang mengatur tentang sanksi pidana, undang-undang khusus lainnya memiliki alternatif lain dalam pengaturan sanksi terhadap korporasi, sanksi tersebut adalah sanksi administratif, beberapa peraturan pemerintah dan peraturan menteri serta peraturan perundang-undangan yang mengatur khusus sanksi administratif, sebagai berikut (Mardiya, 2018):

Pasal 190 ayat (2) UU Ketenagakerjaan menyebutkan "Sanksi administratif sebagaimana dimaksud dalam ayat (1) berupa teguran, peringatan tertulis, pembatasan kegiatan usaha, pembekuan kegiatan usaha, pembatalan persetujuan, pembatalan pendaftaran, penghentian sementara sebagian atau seluruh alat produksi dan pencabutan ijin”. Penjelasan Pasal 190 ayat (2) UU Ketenagakerjaan menyebutkan bahwa sanksi administratif terhadap korporasi tidak lain menyertakan teguran tertulis. Sanksi teguran tertulis ini belum dapat menunjukkan eksistensi hukum yang adil sehingga penerapan hukumnya belum memberikan efek jera bagi korporasi yang melakukan pelanggaran baik pelanggaran ringan maupun berat (Panambunan, 2016).

Pasal 102 ayat (1) UU Pasar Modal bahwa "Bapepam mengenakan sanksi administratif atas pelanggaran UU ini dan atau peraturan pelaksanaannya yang dilakukan oleh setiap pihak yang memperoleh izin, persetujuan, atau pendaftaran dari Bapepam”, Pasal 102 ayat (2) UU 
Pasar Modal menyebutkan "Sanksi administratif sebagaimana dimaksud dalam ayat (1) dapat berupa peringatan tertulis, denda yaitu kewajiban untuk membayar sejumlah uang tertentu, pembatasan kegiatan usaha, pembekuan kegiatan usaha, pencabutan izin usaha, pembatalan persetujuan dan pembatalan pendaftaran”. UU Pasar Modal menerapkan sanksi administratif yang sama yakni berupa sanksi teguran tertulis. Dari kebanyakan peraturan perundangundangan yang menerapkan sanksi teguran tertulis menjadi peringatan berupa tertulis terhadap pihak korporasi yang melakukan palanggaran. Namun bahwasanya sanksi teguran tertulis ini belum dapat merubah korporasi menjadi lebih baik karena telah dihukum atas pelanggarannya. Penerapan sanksi teguran tertulis tidak mencerminkan tujuan hukum yang sebenarnya yakni memberikan efek jera terhadap korporasi yang telah melanggar undangundang (Raganatha, 2017).

Pasal 61 PP Tentang Penyelenggaraan Kegiatan Di Bidang Pasar Modal menyebutkan “Emiten, Perusahaan Publik, Bursa Efek, Lembaga Kliring dan Penjaminan Penyelesaian, Reksa Dana, Perusahaan Efek, Penasehat Investasi, Wakil Penjamin Emisi Efek, Wakil Perantara Pedagang Efek, Wakil Manajer Investasi, Biro Administratif Efek, Kustodian, Wali Amanat, Profesi Penunjang Pasar Modal dan Pihak lain yang telah memperoleh izin, persetujuan, atau pendaftaran dari Bapepam, serta direktur, komisaris, dan setiap Pihak yang memiliki sekurang-kurangnya 5\% (lima per seratus) saham Emiten atau Perusahaan Publik, yang melakukan pelanggaran atas ketentuan peraturan perUndang-undangan di bidang Pasar Modal dikenakan sanksi administratif berupa peringatan tertulis, denda yaitu kewajiban untuk membayar sejumlah uang tertentu, pembatasan kegiatan usaha, pembekuan kegiatan usaha, pencabutan izin usaha, pembatalan persetujuan dan pembatalan pendaftaran”. Masing-masing perusahaan penyelenggara di bidang pasar modal yang disebutkan Pasal 61 UU Tentang Penyelenggaraan Kegiatan di Bidang Pasar Modal di atas sanksi administratifnya adalah sanksi peringatan tertulis yang menjadi sanksi pertama yang perlu dipertimbangkan untuk penjatuhan hukum (Setiadi, 2018). Sebagian UU diatas menyebutkan bahwa sanksi peringatan tertulis adalah bentuk lain dari sanksi teguran. Sanksi peringatan tertulis atau teguran juga belum mencerminkan arti hakikat hukum yang sesungguhnya karena penerapannya belum menunjukkan tujuan hukum yang sebenarnya (Pakpahan, Wijaya, Fortunata, Johny, Muhammad, 2019).

Pasal 59 ayat (2) PP Tentang Pengupahan menyebutkan "sanksi administratif yang diberlakukan berupa teguran tertulis pembatasan kegiatan usaha, penghentian sementara 
sebagian atau seluruh alat produksi, dan pembekuan kegiatan usaha”. PP Tentang Pengupahan menyebutkan bahwa salah 1 (satu) sanksi administratifnya berupa teguran tertulis. Penerapan sanksi teguran tertulis ini faktanya belum menjadikan pihak korporasi kearah yang lebih baik atas kebijakan hukum dalam menegurnya melalui sanksi teguran tertulis UU Pengupahan. Kebijakan ini diterapkan pada korporasi yang melakukan pelanggaran terkategori ringan. Sehingga penerapan sanksinya bukan pidana namun sanksi administratif. Tetapi sanksi teguran tertulis undang-undang pengupahan tidak memberikan efek jera dari pelaksanaannya (Octaviani dan Suardana, 2019).

Pasal 2 ayat (1) Permenaker Tentang Tata Cara Pemberian Sanksi Administratif menyebutkan "Sanksi administratif berupa; teguran tertulis, pembatasan kegiatan usaha, penghentian sementara sebagian atau seluruh alat produksi, dan pembekuan kegiatan usaha”. Teguran tertulis yang dimaksud Pasal 2 ayat (1) Permenaker Tentang Tata Cara Pemberian Sanksi Administratif adalah daftar sanksi yang dapat diberlakukan terhadap korporasi yang melakukan pelanggaran. Sanksi teguran tertulis yang diatur Permenaker Tentang Tata Cara Pemberian Sanksi Administratif belum juga dapat mengedepankan tujuan hukum yang sebenarnya (Manik, Hendrawati dan Suhartoyo, 2016).

Sanksi teguran tertulis ditujukan bila korporasi hanya melakukan pelanggaran ringan, tetapi kebijakan penerapan sanksi tersebut masih belum memberikan kepastian hukum (efek jera) karena meningkatnya tingkah laku korporasi menjadi bentuk kejahatan, dimana hasil akhirnya aparat penegak hukum (APH) harus memberikan sanksi pidana (Nugraha dan Putrawan, 2018). Hal ini sudah tidak efektif sejak awal penerapannya dilakukan dari sanksi teguran tertulis, oleh sebab itu perlunya sanksi teguran yang dilakukan oleh hakim dapat memberikan efek jera kepada korporasi sehingga korporasi tidak melakukan pelanggaran yang memandang rendah hukum dimasa yang mendatang (Rompas, 2018).

Korporasi yang melakukan pelanggaran dapat dikenakan sanksi pidana kumulatif dan sanksi administratif (Trihardianto, 2018). Bentuk sanksi yang paling tepat untuk diterapkan terhadap korporasi yang melakukan pelanggaran berupa sanksi yang tidak dilaksanakan oleh korporasi yang bergerak dibidang perekonomian, pendidikan, usaha, dan lain-lainnya harus diatur secara eksplisit atau jelas, teliti, dan tegas serta diatur dalam peraturan perundangundangan khusus (Usmita, 2019). Jenis sanksi korporasi yang dapat diterapkan dibagi menjadi dua pemaknaan, sanksi yang bermakna imbalan positif dan sanksi bermakna imbalan negatif. 
"Sanksi yang bermakna imbalan positif merupakan penghargaan yang diwujudkan dengan pemberian fasilitas atau insentif pajak, sedangkan sanksi yang bermakna imbalan negatif adalah sanksi administratif” (Ayu, 2013).

\section{b. Sanksi Pidana}

Sanksi Pidana yang diterapkan terhadap korporasi berupa pidana pokok dan pidana tambahan. 2 (dua) sanksi pidana tersebut merupakan suatu bentuk sanksi pidana yang paling pertama telah ada dan paling tertua sejak dahulu ((Prasetyo, Ma'ruf dan Mashdurohatun, 2017). Dalam kajian sanksi pidana terhadap korporasi penulis akan mengulas tentang sanksi pidana denda dan pidana tambahan yang mengatur tentang korporasi di beberapa pengaturan perundang-undangan di Negara Indonesia, sebagai berikut:

\section{Pidana Denda}

Dari beberapa peraturan perundang-undangan yang penulis teliti, terdapat beberapa peraturan perundang-undangan yang memiliki ketetapan khusus mencantumkan pidana denda sebagai pidana pokok atas pelanggaran korporasi, peraturan tersebut menyebutkan sebagai berikut:

UU Tentang Psikotropika menyebutkan "pidana denda yang dapat dijatuhkan kepada korporasi adalah berupa pidana denda sebesar 2 (dua) kali yang diancamkan”. Ini menjelaskan bahwa pidana denda dalam Undang-undang ini akan memberikan denda yang beratnya mencapai 2 (dua) kali lipat, sehingga besarnya ancaman akan mempengaruhi kerugian yang dialami korporasi, namun begitu juga sebaliknya jika kecil ancamannya maka tidak akan memberikan efek jera terhadap korporasi yang pernah melakukan kejahatan (Zainal, 2013).

Pasal 45 Undang-Undang Nomor 23 Tahun 1997 Tentang Pengelolaan Lingkungan Hidup (UU Tentang Pengelolaan Lingkungan Hidup) menyebutkan "pidana yang dapat dijatuhkan kepada korporasi adalah pidana denda dengan diperberat 1/3 (sepertiga)”. Jumlah pidana denda yang diancamkan merupakan jumlah denda yang normal namun jika diperberat 1/3 (sepertiga) dari jumlah awal maka akan mempengaruhi jumlah denda atau menambah denda awal menjadi semakin banyak (Rangkuti, 2018).

Pasal 20 ayat (7) UU Tentang Pemberantasan Tindak Pidana Korupsi menyebutkan “pidana pokok yang dapat dijatuhkan kepada korporasi adalah pidana denda dengan ketentuan maksimum pidana ditambah dengan 1/3 (sepertiga)”. Undang-undang Korupsi mengatur 
sanksi pidana bagi kejahatan yang dilakukan oleh korporasi, namun berbeda dari undangundang lainnya bahwa undang-undang ini menegaskan pidana pokok korporasinya adalah pidana denda, dimana hampir serupa dengan undang-undang sebelumnya, bahwa denda akan diperberat 1/3 (sepertiga) dari jumlah denda awal, sehingga jumlah denda yang diperberat dapat memberikan efek jera atau bahkan sebaliknya tidak memberikan efek jera, tergantung ditentukan berapa jumlah denda yang akan diancamkan tersebut (Saputra, 2016).

Pasal 5 ayat (1) UU Tentang Pencegahan dan Pemberantasan Tindak Pidana Pencucian Uang menyebutkan "pidana pokok yang dijatuhkan terhadap korporasi adalah pidana denda, dengan ketentuan maksimum pidana denda ditambah 1/3 (sepertiga)”, Pasal 7 ayat (1) menyebutkan "dimana ditentukan pidana pokok bagi korporasi adalah pidana denda paling banyak Rp. 100.000.000.000,00 (seratus miliar rupiah)”, Pasal 9 ayat (1) menyebutkan “dalam hal korporasi tidak mampu membayar pidana denda sebagaimana dimaksud dalam Pasal 7 ayat (1) pidana denda tersebut diganti dengan perampasan Harta Kekayaan milik Korporasi atau Personil Pengendali Korporasi yang nilainya sama dengan putusan pidana denda yang dijatuhkan”. Hampir serupa dari undang-undang sebelumnya bahwa pidana pokok korporasi dalam UU Pemberantasan Tindak Pidana Pencucian Uang adalah pidana denda. Namun yang membedakan dari undang-undang sebelumnya adalah jumlah denda sudah ditetapkan khusus oleh Pasal 7 ayat (1) UU Tentang Pencegahan dan Pemberantasan Tindak Pidana Pencucian Uang berupa denda yang tertera sebesar Rp. 100.00.000.000,00 terbilang seratus miliar rupiah, ini disebut sebagai minimum khusus, jumlah minimum khusus akan ditambahkan dengan 1/3 (sepertiga) dari jumlah awal, sehingga denda tersebut akan lebih menjadi lebih banyak. Namun dalam Pasal 9 ayat (1) menegaskan jika denda tidak dapat dibayarakan maka harta kekayaan korporasi dan personil pengendali korporasi sebagai gantinya akan dirampas sesuai dengan taraf jumlah denda yang telah ditambah 1/3 (sepertiga) tersebut (Serbabagus, 2017).

Undang-undang khusus di luar KUHP mengatur sanksi pidana denda sebagai sanksi yang dapat dijatuhkan pidana kepada korporasi yang melakukan pelanggaran. Setelah dikemukakan rumusan sanksi di atas tentu hal ini akan memberikan dampak berupa kurangnya harta korporasi karena berkewajiban membayar denda ganti kerugian atas pelanggaran yang telah dilakukannya. Selain harus ditetapkannya ketentuan yang mengatur sanksi administratif berupa teguran, peringatan tertulis, batasan dalam kegiatan hubungan 
bisnis, denda yang ditentukan untuk membayar sejumlah uang tertentu, penghentian sementara sebagian operasional korporasi atau semua alat produksi, pembekuan korporasi, pembatalan persetujuan dan pembatalan pendaftaran juga perlu dikembangkan suatu sanksi administratif yang pelaksanaannya bersifat tanpa pidana (non-penal) melainkan pengembangan dari sanksi teguran di beberapa peraturan perundang-undangan menjadi sanksi teguran oleh hakim (reprimand) dimuka umum (Widowaty dan Fitriyanti, 2014). Tentu hal ini akan jauh memberikan efek jera di kalangan masyarakat dan mempengaruhi hubungan bisnis korporasi.

Mengikuti dari beberapa peraturan perundang-undangan yang telah dicantumkam diatas bahwa semua pengadilan dapat menjatuhkan sanksi pidana pokok kepada korporasi, seperti: (1) UU Psikotropika 2 (dua) kali terancam; (2) UU Pengelolaan Lingkungan Hidup sepertiga hukuman penjara; (3) UU Pemberantasan Korupsi hukuman dengan batas sepertiga (1/3); (4) UU Pencegahan dan Pemberantasan Tindak Pidana Pencucian Uang berupa denda yang tertera sebesar Rp. 100.00.000.000,00 (Santo, 2016). Perjanjian hukuman yang tidak jelas seperti yang disebutkan di atas akan memengaruhi bentuk tidak ada klausul atau undangundang yang dapat mendorong kemitraan yang tidak perlu membayar denda atau melakukan pembayaran kompensasi. Hukum harus diterapkan untuk mengatur pengaturan pembayaran atau keputusan pemberian ganti rugi, pencabutan izin usaha atau likuidasi, diikuti dengan likuidasi sesuai dengan UU Pencegahan dan Pemberantasan Pencucian Uang (Onibala, 2015).

\section{Pidana Tambahan}

Beberapa sanksi pidana tambahan yang diatur dalam peraturan perundang-undangan yang mengatur ketentuan sanksi tersebut, sebagai berikut:

Pasal 10 huruf b Pidana tambahan KUHP menyebutkan tentang "pengumuman putusan hakim”. Dalam penerapannya sanksi pengumuman putusan hakim hampir belum pernah di terapkan di pengadilan Indonesia (Wulansari, 2019). Sehingga eksistensi formulasi sanksi pengumuman putusan hakim ini tidak dapat diaplikasikan terhadap korporasi yang menyimpang dari peraturan perundang-undangan.

Pasal 7 Undang-Undang Nomor 7 Darurat tahun 1955 Tentang Tindak Pidana Ekonomi (UU Tentang Tindak Pidana Ekonomi) menyebutkan “penutupan seluruhnya atau sebagian perusahaan si terpidana, perampasan barang tidak tetap yang berwujud maupun tidak berwujud termasuk perusahaan si terpidana yang diperoleh dari tindak pidana ekonomi, 
pencabutan seluruh atau sebagian hak-hak tertentu atau penghapusan seluruh atau sebagian keuntungan tertentu, yang telah atau dapat diberikan kepada si terpidana oleh Pemerintah berhubung dengan perusahaannya, untuk waktu selama-lamanya dua tahun, dan sanksi berupa pengumuman putusan hakim”. Sanksi berupa pengumuman putusan hakim tidak diatur secara ekslipisit seperti apa pengumuman tersebut dan ukuran lamanya berlaku terhadap kualitas pelanggaran korporasi yang belum terbilang tegas jenis pelanggarannya (Ramelan, 2018).

Pasal 91 UU Tentang Narkotika menyebutkan "berupa pencabutan hak sesuai dengan peraturan perundang-undangan yang berlaku, tidak diatur secara eksplisit mengenai pidana tambahan yang dapat dijatuhkan kepada korporasi”. Dewasa ini sanksi pencabutan hak atas pelanggaran yang dilakukan korporasi belum dibahas secara jelas maksud dari penerapan pencabutan hak ini. Pidana tambahan dalam UU Narkotika masih tergolong belum rinci maksud dari pencabutan hak korporasi ini (Sujasmin, 2010).

Undang-Undang Nomor 23 Tahun 1997 Tentang Pengelolaan Lingkungan Hidup (UU Tentang Pengelolaan Lingkungan Hidup) Perumusan pidana tambahan korporasi tidak diatur secara eksplisit (tegas dan jelas), tetapi rincian isinya dijelaskan kedalam kategori tindakan tata tertib korporasi sebagaimana telah diatur Pasal 47 UU Tentang Pengelolaan Lingkungan Hidup. Walau demikian "jenis tindakan tata tertib berupa perampasan keuntungan dan penutupan perusahaan yang diatur dalam Pasal 47”, kebanyakan yang terjadi pada pasal-pasal diatas hampir secara perataan pidana tambahan bagi korporasi belum diatur secara lengkap, sehingga dampaknya adalah sanksi yang diberikan hanya berupa perampasan/penyitaan harta dan pencabutan izin korporasi (Satria, 2017).

Pasal 5 ayat (2) UU Tentang Pencegahan dan Pemberantasan Tindak Pidana Pencucian Uang menyebutkan "Selain pidana denda sebagaimana dimaksud dalam ayat (1) terhadap korporasi juga dapat dijatuhkan pidana tambahan berupa pencabutan izin usaha dan/atau pembubaran korporasi yang diikuti dengan likuidasi”. Perubahan yang ada di dalam UU Tindak Pidana Pencucian Uang yang sekarang hanya menambahkan sanksi pidana tambahan berupa pencabutan izin usaha dan/atau pembubaran korporasi yang diikuti dengan likuidasi untuk korporasi. Sama halnya seperti undang-undang yang sebelumnya, yang berarti belum kuat dapat memberikan efek jera (Arifin dan Choirinnisa, 2019).

Dari beberapa undang-undang diatas yang dimana jenis sanksi pidananya sudah dipaparkan terdapat pidana tambahan. Ada pula beberapa sanksi administratif yang cocok 
untuk kejahatan korporasi itu. Perlu di lakukan formulasi sanksi berupa teguran (reprimand) yang diberikan oleh hakim sebagai sanksi yang efek jeranya berdampak sosial. Sanksi teguran yang diberikan oleh hakim akan mempengaruhi nama baik korporasi di masyarakat dan mempengaruhi reputasi untuk bekerjasama antar korporasi (Wulansari, 2019). Pencabutan sebagaimana disinggung terdiri dari hak untuk memegang jabatan, hak untuk memindahkan angkatan bersenjata dan hak untuk menjalankan pencaharian tertentu (Kristian, 2017). Perumusannya terdiri dari pidana tambahan yang tidak ditulis dimaksudkan secara jelas. Pencabutan hak terhadap korporasi oleh undang-undang yang relevan harus dirumuskan untuk dipertimbangkan, oleh sebab itu bentuk pidana tambahan harus dimaksudkan secara jelas agar dapat diberlakukan kepada korporasi (Suhariyanto 2016).

\section{Kebijakan Formulasi Sanksi Teguran (Reprimand) Oleh Hakim Terhadap Kejahatan Korporasi Dimasa Yang Akan Datang}

Kebijakan formulasi dapat dikatakan sebagai kebijakan membuat undang-undang atau politik hukum. Membuat undang-undang merupakan membuat keseluruhan peraturan yang berkaitan dengan kebijakan dalam hukum (Arief, 2018). Menurut Sudarto bahwa kebijakan hukum merupakan kebijakan yang diluar akal sehat manusia, dipengaruhinya faktor ekonomi yang mengandung asas atau pedoman pelaksaan sanksi terhadap pelanggaran hukum adalah sebagai berikut (Sudarto, 2013): Dalam arti luas, keseluruhan fungsi dari aparatur penegak hukum (APH), termasuk didalamnya teknis fungsional kerja dari kepolisian, jaksa dan pengadilan”, dalam arti yang paling luas, beliau mengemukakan dengan berdasarkan pendapat dari Jorgen Jopsen, bahwa keseluruhan kebijakan yang dilakukan melalui perundangundangan dan badan-badan resmi bertujuan untuk menegakan norma-norma sentral dari masyarakat” (Febrikusuma, Soponyono, dan Purwoto, 2016).

Definisi singkat yang dikemukakan oleh Barda Nawawi Arief, bahwa politik kriminal merupakan suatu upaya yang rasional (logis) untuk menanggulanggi suatu bentuk yang menyimpang dari masyarakat atau penguasa dan pemerintah (Arief, 2014). Sudarto pernah menyatakan bahwa melaksanakan suatu politik hukum berarti melakukan proses evaluasi terhadap fakta untuk dilakukan pertimbangan yang selektif demi mencapai hasil perundangundangan sebagai yang paling baik dalam arti terpenuhinya syarat keadilan (Sudarto, 2013). 
Penerapan sanksi teguran oleh hakim terhadap korporasi dalam menegakkan keadilan terhadap pelanggaran korporasi dalam hal ini merupakan sanksi teguran yang bukan bersifat pidana (non-penal), kemudian ukuran lama sanksi teguran oleh hakim merupakan kebijakan keputusan hakim dengan mempertimbangkan ukuran pelanggaran yang dilakukan oleh korporasi, sehingga dibatasinya penyiaran ke media umum tentang pelanggaran korporasi oleh jumlah waktu yang ditentukan hakim berdasarkan kebijakan dalam putusannya. Ukuran lama sanksi teguran tersebut diukur dari kualitas pelanggaran yang dilakukan oleh korporasi, sedangkan pihak yang berwenang untuk menjatuhkan sanksi teguran adalah hakim di dalam pengadilan, kemudian hakim mencela korporasi berdasarkan terbuktinya melakukan pelanggaran, kemudian teguran oleh hakim dipublikasikan dalam media cetak, koran, surat kabar, berita dan sumber informasi lainnya (Kristian, 2017). Teguran yang diberikan oleh hakim tentu akan mempengaruhi baik atau buruknya korporasi dalam perjalanannya kedepan (Amarini, 2016). Dalam berbagai peraturan perundang-undangan negara asing ada beberapa negara yang sudah memformulasikan sanksi teguran (reprimand) bagi subyek hukum oleh saksi, korban, dan pihak sipil. Terdapat beberapa peraturan perundang-undangan luar negeri dari negara asing yang mengatur sanksi teguran oleh hakim dalam kebijakannya untuk kemudian penulis lakukan kajian komparatif seperti antara lain:

Pengaturan Sanksi di Negara Portugal (Pasal 60 Teguran): "If the agent ought to be sentenced to a fine of a measure not superior to 120 days, the court may limit itself to pronounce an reprimand", "Reprimand only takes place if the damage has been repaired and the court concludes that, doing so, the aims of punishment will be accomplished in an appropriate and sufficient way", "As a rule, reprimand will not be used if the agent, during the 3 years prior to the act, has been sentenced to whatever penalty, including reprimand", "Reprimand consists of a solemn oral censure made in session by the court to the agent".

Mengacu pada pengaturan sanksi korporasi dari Negara Portugal bahwa pengaturan di atas menjelaskan suatu pelanggaran yang dilakukan oleh korporasi dapat dikenakan sanksi peringatan/teguran (reprimand) apabila ancaman pidananya tidak lebih dari 120 hari, kemudian sanksi peringatan/teguran (reprimand) hanya berlaku pada korporasi yang memang dari awal belum pernah terjerat perbuatan yang melawan hukum, serta korporasi bertanggungjawab dengan sudah memperbaiki dampak kerusakan dari perbuatannya, maka hakim dapat memberikan sanksi peringatan/teguran (reprimand) berupa celaan lisan yang serius terkait perbuatan tersebut. 
Celaan tersebut diberikan langsung oleh hakim di dalam putusan pengadilan, sehingga sifat sanksi yang dijatuhkan bukan pidana. dengan ini menunjukkan bahwa di Negara Portugal menerapkan sanksi teguran oleh hakim terhadap korporasi yang sama sekali belum pernah melakukan perbuatan yang melawn hukum. Dampak (impact) daripada sanksi ini ditujukan kepada korporasinya bukan orang yang bekerja di dalamnya, penerapan sanksi teguran oleh hakim terhadap korporasi akan sangat efektif untuk mengkondusifkan korporasi yang menyimpang dari aturan dan meresahkan masyarakat, dimana dampak (impact) sesungguhnya akan membebankan pada kerugian materil korporasi itu sendiri (Wibisana, 2016).

Pengaturan Sanksi di Negara Perancis [Pasal 222 (3)]: “5ªgainst a witness, victim or civil party, either to prevent him from denouncing the action, filing a complaint or making a statement before a court, or because of such denunciation, complaint or statement", "A denunciation made by any means and directed against a specified person, of a fact that is liable to cause judicial, administrative or disciplinary sanctions and that the maker knows to be totally or partially false, where it is sent either to a judicial officer or to a judicial or administrative police officer, or to an authority with power to follow it up or to refer it to the competent authority, or to hierarchical superiors or to the employer of the person concerned, is punished by five years' imprisonment and a fine of $€ 45,000 ”$.

Mengacu pada isi pengaturan sanksi teguran oleh hakim dari Negara Perancis diatas bahwa pihak sipil, saksi, korban, dapat memberikan pernyataan karena penolakan yang dilakukan oleh korban kepada pelaku dengan peringatan/teguran (reprimand) di depan pengadilan. Dilanjutkan dengan bunyi selanjutnya jika kecaman atau teguran (reprimand) diarahkan pada pihak-pihak tertentu dari suatu fakta baik seluruh ataupun sebagian yang sampai melibatkan pengadilan, dan sanksi-sanksi lainnya dengan ditunjuk beberapa orang untuk menindaklanjutinya. Penjelasan pasal ini selain mengatur tentang sanksi teguran (reprimand) juga memberikan sanksi pada pihak tertentu yang melakukan pencelaan sembarangan yang bukan oleh hakim maka dikenakan sanksi sebagai hukuman. Hal ini menjelaskan bahwa korporasi sebagai pihak sipil harus dijatuhkan pencelaan hanya oleh hakim melalui prosedur pengadilan.

Pencelaan merupakan bagian dari pencorengan moralitas, nama baik, kehormatan, dan lain-lain yang membebankan pihak untuk bertanggungjawab penuh terhadap perbuatan buruk yang dilakukan (Santoso, 2016). Di zaman modern pencelaan dimanifestasikan sebagai singgungan konsekuensi yang menyudutkan salah satu pihak, tetapi merupakan hal yang lumrah dalam bahasa sehari-hari yang disebut dengan kritik umum di masyarakat (public). Beratnya suatu tindakan maka akan mempengaruhi berat sanksi. Menurut beliau dibutuhkan 
penyesuaian proporsionalitas antara kesalahan pelanggar dan seriusitas pihak tercela (Luna, 2003). Semakin tinggi pencelaan yang dilakukan seseorang maka semakin mempengaruhi berat perlakuan psikis/mental yang diterima pelaku (Lee, 2007).

Pendapat Hirsch mengatakan penggunaan bobot sanksi yang merujuk pada teori proporsionalitas disebabkan pergeseran konsep pembalasan menjadi mempengaruhi para pelanggar untuk kembali melakukan pelanggaran yang dilakukan kepada konsepsi pencelaan sanksi (Ali, 2018). Perumusan sanksi teguran (reprimand) oleh hakim di dalam peraturan perundang-undangan Negara Portugal dan peraturan perundang-undangan Negara Perancis dapat menjadi contoh untuk memperkuat sanksi-sanksi yang diterapkan pada pelanggaran korporasi di Negara Indonesia, dengan diformulasikannya kebijakan sanksi teguran (reprimand) oleh hakim di Negara Indonesia terkhususnya bagi pelanggaran korporasi demi mewujudkan tujuan hukum berupa keadilan adalah dengan penerapan sanksi teguran (reprimand) yang diucapkan oleh hakim di muka umum akan menyangkut moralitas, nama baik, dan kehormatan korporasi yang melakukan pelanggaran (Prasetyo, Ma'ruf dan Mashdurohatun, 2017). Bobot efek jera yang diterima sangat berdampak dengan turunnya kepercayan masyarakat terhadap kinerja korporasi, berkurangnya saham yang dikeluarkan oleh korporasi, serta berdampak secara sosial global (global sanction) dalam hubungan kerja korporasi antar hubungan internal baik kepada sesama korporasi atau pemerintah. Sanksi teguran (reprimand) oleh hakim ini hanya dilakukan oleh hakim dan bobot teguran (reprimand) yang diberikan sesuai dengan bobot ukuran pelanggaran yang dilakukan korporasi dengan batas tempo hari sanksi yang telah ditentukan oleh hakim.

\section{PENUTUP}

Korporasi disebut sebagai perusahaan oleh beberapa ahli yang bergerak dibidang ekonomi, pendidikan, investasi, dan bidang lainnya. Korporasi menurut beberapa pengaturan perundang-perundangan merupakan sekumpulan orang atau harta kekayaan yang teroganisir dengan baik yang bersifat berbadan hukum maupun bukan berbadan hukum. Korporasi dapat melakukan apa saja yang biasa dilakukan oleh manusia sepanjang masa legalitas korporasi masih dipandang oleh hukum di jalan yang positif menurut undang-undang.

Beberapa pengaturan dalam peraturan perundang-undangan di Indonesia mengatur sanksi korporasi ke dalam 2 (dua) jenis sanksi yakni, sanksi pidana (tambahan) dan administratif. Sanksi pidana tambahan yang dapat diterapkan terhadap korporasi berupa pengumuman putusan hakim, sedangkan sanksi administratif berupa teguran atau peringatan 
tertulis, pembayaran denda sebagai ganti kerugian, pembekuan korporsi, pembatalan izin dan pendaftaran korporasi, serta penyitaan dan perampasan hak. Beberapa pengaturan sanksi terhadap korporasi terdapat kelemahan mengenai penerapannya. Sanksi pidana tambahan pengumuman putusan hakim merupakan sanksi pidana, yang belum dijelaskan secara eksplisit mengenai pelaksanaanya, juga sampai hari ini sanksi teguran administratif masih belum memberikan efek jera terhadap korporasi sehingga jalan terakhir penerapan hukum terhadap korporasi hanya berupa pidana.

Seyogyanya sanksi teguran (reprimand) oleh hakim ini sangat penting bagi korporasi, karena korporasi sangat mengutamakan nama baiknya. Sanksi teguran yang dilakuakn oleh hakim terhadap korporasi akan mencela korporasi tersebut atas pelanggarannya yang kemudian dari perbuatannya akan disebarluaskan di seluruh media cetak, koran, berita hangat, dan sumber informasi lainnya. Pengaruh dampak (impact) yang akan diterima dapat berupa turunnya kepercayan masyarakat terhadap korporasi, penurunan saham penjualan dan pembelian yang dikelola oleh internal korporasi, serta berdampak secara sosial global (global sanction) dalam hubungan kerja korporasi antar hubungan internal baik kepada sesama korporasi atau pemerintah dan pengurus di dalamnya.

\section{REFERENCES}

Ali, M. (2018). Proporsionalitas Dalam Kebijakan Formulasi Sanksi Pidana. Jurnal Hukum Ius Quia Iustum, 25(1), 137-158. DOI: https://doi.org/10.20885/iustum.vol25.iss1.art7

Amarini, I. (2016). Mengefektifkan Sanksi Pidana Korporasi dalam Kasus Pencemaran Lingkungan (Analisis Kasus Kebocoran Sumur Minya Montora di Laut Timor). Kosmik Hukum, 16(1), 1-17. DOI: 10.30595/kosmikhukum.v16i1.1272

Anjari, W. (2017). Pertanggungjawaban Korporasi Sebagai Pelaku Tindak Pidana. Jurnal Ilmiah Widya Yustisia, 1(2), 116-121.

Arief, B. N. (2014). Bunga Rampai Kebijakan Hukum Pidana Perkembangan Penyusunan Konsep KUHP Baru. Semarang: Prenamedia Group.

Arifin, R. dan Choirinnisa, S. A. (2019). Pertanggungjawaban Korporasi dalam Tindak Pidana Pencucian Uang dalam Prinsip Hukum Pidana Indonesia. Jurnal Mercatoria, 12(1), 4353. DOI: 10.31289/mercatoria.v12i1.2349

Arofa, E. (2018). Korporasi Sebagai Subjek Hukum Dan Bentuk Pemidanaannya Dalam Tindak Pidana Korupsi. Jurnal Surya Kencana Dua Dinamika Masalah Hukum dan Keadilan, 5(1), 445-458.

Atmaka, A. dan Roestamy, M. (2019). Pertanggungjawaban Bank Sebagai Korporasi Terhadap Terjadinya Fraud. Jurnal Ilmiah Living Law, 11(1), 13-22 . DOI: http://dx.doi.org/10.30997/jill.v11i1.1635

Ayu, I. K. (2013). Analisis Yuridis Pemberian Sanksi Dalam Pelaksanaan Tanggung Jawab Sosial Dan Lingkungan Oleh Perseroan Terbatas Yang Bergerak Di Bidang Sumber Daya Alam, Kumpulan Jurnal Mahasiswa Fakultas Hukum, 1(5), 1-21.

Butarbutar, R. (2016). Pertanggungjawaban Pidana Parta Politik dalam Tindak Pidana Korupsi dan Pencucian Uang. Padjajaran Jurnal Ilmu Hukum, Universitas Padjajaran, Bandung. DOI: https://doi.org/10.22304/pjih.v3n2.a7 
Davadi, L. B. (2017), Pertanggungjawaban Tindak Pidana Korporasi Yang Dibebankan Kepada Pengurus Korporasi Dalam Pasal 59 KUHP. Lex et Societatis 5(7), 79-84.

Erdianti, R. N. (2013). Urgensi Pemidanaan Terhadap Korporasi Sebagai Pelaku Tindak Pidana. Hukum dan Dinamika Masyarakat, 13(1), 39-48. DOI: http://dx.doi.org/10.36356/hdm.v13i1.428

Febrikusuma, T. W., Soponyono E., dan Purwoto. (2016). Kebijakan Hukum Pidana Dalam Upaya Penanggulangan Tindak Pidana Gratifikasi Di Kebupaten Blora. Diponegoro Law Review, 5(2), 1-11.

Hirsch, A. V. (2001). Proportionate Sentences for Juveniles How Different than for Adults?. Punishment and Society, 3(2), 221-236. DOI: https://doi.org/10.1177/1462474501003002002

Kristian, K. (2017). Jenis-Jenis Sanksi Pidana Yang Dapat Ditetapkan Terhadap Korporsi. Jurnal Hukum dan Pembangunan, 43(2), 270-288. DOI: http://dx.doi.org/10.21143/jhp.vol43.no2.1485

Lee, Y. (2007). Punishment as Reluctant Moralism. Criminal Law and Philosophy. 1, 228. DOI: https://doi.org/10.1007/s11572-006-9009-7

Luna, E. (2003). Punishment Theory, Holism and the Procedural Conception of Restorative Justice. Utah Law Review, 216.

Manik, J. M. P. dan Suhartoyo, D. H. (2016). Perlindungan Hukum Terhadap Pekerja/Buruh Wanita Dalam Hubungan Dengan Perusahaan Berdasarkan UU No. 13 Tahun 2003 tentang Ketenagakerjaan (Studi Kasus pada PT. Sido Muncul), Diponegoro Law Review, 5(4), 1-12.

Mardiya, N. Q. (2018). Pengaturan Pertanggungjawaban Korporasi Dalam Tindak Pidana Lingkungan Hidup, Jurnal Hukum dan Peradilan, 7(3), 483-502. DOI: http://dx.doi.org/10.25216/JHP.7.3.2018.483-502

Marnelly, T. R. (2012). Corporate Social Responsibility (CSR) Tinjauan Teori Dan Praktek Di Indonesia. Jurnal Aplikasi Bisnis, 2(3), 49-59.

Nugaraha, M. S. W. dan Putrawan, S. (2018). Pemberian Sanksi Pidana Sebagai Ultimum Remedium Dalam UU Perlindungan dan Pengelolaan Lingkungan Hidup. Kertha Wicara: Journal Ilmu Hukum, 7(2), 1-12.

Octaviani, I. D. A. M., dan Suardana, I .W. (2019). Tanggung Jawab Pelaku Usaha Terhadap Pekerja/Buruh Terkait Keterlambatan Pembayaran Upah Lembur, Kertha Semaya: Journal Ilmu Hukum, 7(11), 1-14. DOI: https://doi.org/10.24843/KM.2019.v07.i03.p13

Onibala, A.T. (2015). Penerapan Sanksi Hukum Terhadap Kejahatan Menurut UU No. 8 Tahun 2010. Lex Crimen, 4(6), 82-89.

Pakpahan, E. F., Wijaya, S. F., Fortunata, A., Johny, dan Muhammad, H. (2019). Benturan Kepentingan Bagi Konsultan Hukum Dalam Kejahatan Pasar Modal, Jurnal Ilmiah Penegakkan Hukum, 6(2), 78-85. DOI: http://dx.doi.org/10.31289/jiph.v6i2.2605

Panambunan, A. M. K. (2016). Penerapan Sanksi Administratif Dalam Penegakan Hukum Lingkungan Di Indonesia. Lex Administratum, 4(6), 93-101.

Prasetyo, R.T., Ma'ruf, U. dan Mashdurohatun, A. (2017). Tindak Pidana Korporasi Dalam Perspektif Kebijakan Formulasi Hukum Pidana, Jurnal Hukum Khaira Ummah, 12(4), 727-741.

Puspitasari, I. dan Devintawati, E. (2018). Urgensi Pengaturan Kejahatan Korporasi Dalam Pertanggungjawaban Tindak Pidana Korporasi Menurut KUHP. Kanun Jurnal Ilmu Hukum, 20(2),237-254. DOI: https://doi.org/10.24815/kanun.v20i2.10661 
Raganatha, B. S. (2017). Tinjauan Pertanggungjawaban Pidana Bagi Korporasi Yang Melakukan Insider Traiding Dalam Pasar Modal, Refleksi Hukum; Jurnal Ilmu Hukum, 2(1), 17-32. DOI: https://doi.org/10.24246/jrh.2017.v2.i1.p17-32

Ramelan, Y. (2018). Penerapan Sanksi Pidana Korporasi Pada Bank Dan Implikasinya. Jurnal Hukum dan Pembangunan, 48(4), 8651-882. DOI: http://dx.doi.org/10.21143/jhp.vol48.no4.1806

Rangkuti, R. (2018). Pertanggungjawaban Korporasi Terhadap Tindak Pidana Lingkungan Hidup Menurut UU No. 23 tahun 1997. Justisia, 1(1), 253-270.

Rifai, E. (2014). Perspektif Pertanggungjawaban Pidana Korporasi Sebagai Pelaku Tindak Pidana Korupsi. Mimbar Hukum fakultas Hukum Universitas Gadjah Mada, 26(1), 87101. DOI: https://doi.org/10.22146/jmh.16056

Rifki, M. (2019). Reformulasi Sanksi Administrasi Bersifat Primum Remedium Dalam Pengelolaan Perikanan (Sebuah Upaya Memberi Efek Jera Bagi Korporasi Pelanggar Ketentuan Di Bidang Perikanan). Esensi Hukum, 1(1), 51-69.

Rompas, Y. D. (2018). Pertanggungjawaban Korporasi Dalam Usaha Pemanfaatan Hutan Tanpa Izin. Lex Et Societatis, 6(7), 22-30. DOI: 10.1017/CBO9781107415324.004

Santo, P. A. F. D. (2012). Tinjauan Tentang Subyek Hukum Korporasi dan Formulasi Pertanggungjawaban dalam Tindak Pidana. Humaniora, 2(2), 422-437. DOI: https://doi.org/10.21512/humaniora.v3i2.3342

Santoso, M. A. (2016). Pertanggungjawaban Pidana Pencemaran Lingkungan Hidup Yang dilakukan Oleh Korporasi. Jurnal Cakrawala Hukum, 7(2), 216-228. DOI: 10.26905/idjch.v7i2.1912

Saputra, R. (2016). Pertanggungjawaban Pidana Korporasi dalam Tindak Pidana Korupsi. Jurnal Cita Hukum, FSH UIN Syarif Hidayatullah Jakarta, 3(2), 269-288. DOI: 10.15408/jch.v2i2.2318.2015.3.2.269-288

Satria, H. (2017). Penerapan Pidana Tambahan Dalam Pertanggungjawaban Pidana Korporasi Pada Tindak Pidana Lingkungan Hidup. Jurnal Yudisial, 10(2), 155-171. DOI: http://dx.doi.org/10.29123/jy.v10i2.18

Schneider, G. S. (2012). Sentencing Proportionality In The States. Arizona Law Review, 54, 241-275.

Serbabagus, S. (2017). Pertanggungjawaban Korporasi Pada Tindak Pidana Pencucian Uang (Money Laundering). Yurijaya, 1(1), 1-12.

Setiadi, W. (2018). Sanksi Administratif Sebagai Salah Satu Instrumen Penegakan Hukum Dalam Peraturan Perundang-Undangan. Jurnal Legislasi Indonesia, 6(4). 603-614.

Setiyono, H. (2005). Kejahatan Korporasi, Analisis, Viktimologis Dan Pertanggungjawaban Korporasi Dalam Hukum Pidana Indonesia. Malang: Bayumedia Publishing.

Sudarto. (2013). Hukum Pidana I. Semarang: Yayasan Sudarto d/a Fakultas Hukum Undip

Suhariyanto, B. (2016). Progresivitas Putusan Pemindanaan Terhadap Korporasi Pelaku Tindak Pidana Korupsi. Jurnal Penelitian Hukum De Jure, 16(2), 201-213. DOI: ttp://dx.doi.org/10.30641/dejure.2016.V16.201-213

Sujasmin, S. (2014). Rasionalitas Penetapan Pidana Tambahan Dalam Penanggulangan Kejahatan Korporasi di Bidang Narkoba. Jurnal Wawasan Yuridika, 22(1), 67-91. DOI: http://dx.doi.org/10.25072/jwy.v22i1.4

Trihardianto, R. (2018). Terhadap Hak Penyandang Disabilitas Di Bidang Ketenagakerjaan Dalam Undang- Penyandang Disabilitas Criminal Responsibilities of the Corporate Toward the Rights of People With Disabilities in the Field of Employment According To Law Number 8 of 2016 Concer. IUS, 6(1), 50-61. DOI: http://dx.doi.org/10.29303/ius.v6i1.537 
Usmita, F. (2019). Penghukuman Bagi Korporasi Perusak Lingkungan. Jurnal Ilmiah Dinamika Sosial, 3(2), 211-233

Wibisana, A. G. (2016). Kejahatan Lingkungan Oleh Korporasi: Mencari Bentuk Pertanggungjawaban Korporasi Dan Pemimpin/Pengurus Korporasi Untuk Kejahatan Lingkungan Di Indonesia?. Jurnal Hukum \& Pembangunan, 46(2), 149-195. DOI: http://dx.doi.org/10.21143/jhp.vol46.no2.74

Widowaty, Y. dan Fitriyanti, F. (2014). Membangun Model Perlindungan Hukum terhadap Masyarakat Sebagai Korban Pencemaran dan/atau Perusakan Lingkungan Oleh Korporasi Dengan Prinsip Restorative Justice, Jurnal Media Hukum, 21(1), 1-19.

Wulansari, F. (2019). Pemenuhan Hak Korporasi Sebagai Korban Tindak Pidana Pencemaran Nama Baik. Jurist Diction, 2(2), 435-458. DOI: http://dx.doi.org/10.20473/jd.v2i2.14227

Zainal, A. (2013). Penegakkan Hukum Terhadap Kejahatan Narkotika Ditinjau Dari Aspek Kriminilogi. Jurnal Al-Adl, 6(2), 44-61. 